\title{
Biografar os grandes homens para trazê-los à História de uma nova forma: Plutarco e [as interseções de] um mesmo gênero*
}

\section{Profiling great men to bring them to history in a new way: Plutarch and [the intersections of] genres}

\author{
Lorena Lopes da Costa \\ lorenalopes85@gmail.com \\ Doutora em História \\ Professora Adjunta de Teoria da História \\ Universidade Federal do Oeste do Pará \\ Campus Rondon - Av. Marechal Rondon, s/n, Caranazal \\ 68040-070 - Santarém - Pará \\ Brasil
}

\section{Resumo}

Neste artigo são discutidos, a partir de algumas passagens de Vidas, de Plutarco, os gêneros biografia e história com vistas a refletir se, na perspectiva de Plutarco, eles constituiriam gêneros distintos ou um mesmo gênero que se localizaria, assim, na História da Historiografia. Para tanto, faz-se uma genealogia da biografia a partir dos elementos da tradição grega que permanecem em Plutarco e toma-se, ainda, para estudo de caso, uma passagem específica da Vida de Alexandre. Mediante esse percurso, visa-se propor que a maior contribuição de Plutarco não teria sido propriamente estabelecer fronteiras fixas entre história e biografia, mas, na verdade, apresentar os grandes nomes da história de uma nova forma, revelando também suas passagens menos gloriosas e até anedóticas, tirando-lhes, por vezes, a armadura de herói para dar-lhes a roupagem de homens, de carne e osso, às vezes virtuosos, às vezes vis e às vezes ambíguos.

\section{Palavras-chave}

História; Biografia; Gêneros literários.

\begin{abstract}
This paper analyzes the genres biography and history through some passages of Lives (Plutarch), in order to establish if they constitute distinct genres or - under the author's perspective - the same one, therefore positioning him in the history of historiography. With this purpose, we search the origins of biographies highlighting elements of the Greek tradition that remain in Plutarch, performing a case study of a fragment from Life of Alexander. The discussion proposes that Plutarch's purpose was not establishing clear boundaries between history and biography, but rather to make great men more evident to history in a new way, revealing less glorious and even ludicrous passages of their lives, taking off their armors and giving them the garb of common men, sometimes virtuous, sometimes nasty, and ultimately ambiguous.
\end{abstract}

Keywords

History; Biography; Literary genres.

Recebido em: 29/6/2017

Aprovado em: 13/12/2017

\footnotetext{
* Este texto é resultado das instigantes discussões sobre Plutarco que aconteceram às terças e quintas-feiras no primeiro e segundo semestres de 2014, no Seminário em Língua Grega ministrado pelo Prof. Olimar Flores, na Faculdade de Letras da UFMG. Sou muito grata a ele e aos colegas de turma.
} 
Por uma gênese do gênero biográfico e sua relação com a epopeia e a história

Se, como diria o prof. François Hartog (1999, p. 23), na Grécia, tudo começa com a epopeia, então poderíamos supor que história e biografia se enredam muito antes de que a História propriamente dita venha a nascer, no séc. V a. C., com Heródoto e Tucídides, que, por certo, não fazem biografia. O que nos conta a poesia épica senão os grandes feitos de grandes homens, isto é, sua biografia heroica? Sobretudo a Odisseia nos conta os feitos de um grande homem. Em contraste com a Ilíada e com seu objeto, que é a cólera [ $\mu \tilde{\eta} v ı s]$ de Aquiles (a cólera de um herói na guerra), a Odisseia apresenta o herói das muitas experiências, um herói que não foi herói apenas na guerra. É

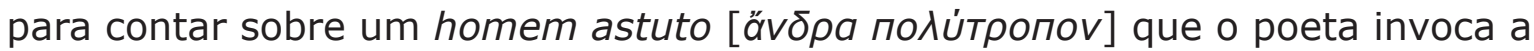
Musa: "Fala-me, Musa, do homem astuto que tanto vagueou" (Odisseia, I, 1). Desde seu proêmio, portanto, na Odisseia o autor deixa explícito que o objeto da obra é um homem, uma vida, uma personagem. A abertura da Odisseia com ăvopa (homem), de fato, parece indicar que a história não será apenas sobre um homem e seu retorno, mas sobre esse homem como homem, em sua condição de homem, líder, marido, pai, filho, mestre e rei (DE JONG 2002).

Fala-me, Musa, do homem astuto que tanto vagueou, depois que de Troia destruiu a cidadela sagrada. Muitos foram os povos cujas cidades observou, cujos espíritos conheceu; e foram muitos no mar os sofrimentos por que passou para salvar a vida, para conseguir o retorno dos companheiros a suas casas. Mas a eles, embora o quisesse, não logrou salvar. Não, pereceram devido à sua loucura, insensatos, que devoraram o gado sagrado de Hipérion, o Sol - e assim lhes negou o deus o dia do retorno. Destas coisas fala-nos agora, ó deusa, filha de Zeus. Nesse tempo, já todos quantos fugiram à morte escarpada se encontravam em casa, salvos da guerra e do mar. Só àquele, que tanto desejava regressar à mulher, Calipso, ninfa divina entre as deusas, retinha em côncavas grutas, ansiosa que se tornasse seu marido. Mas quando chegou o ano (depois de passados muitos outros) no qual decretaram os deuses que ele a Ítaca regressasse, nem aí, mesmo entre o seu povo, afastou as provações. E todos os deuses se compadeceram dele, todos menos Posêidon: e até que sua terra alcançasse, o deus não domou a ira contra o divino Ulisses (Odisseia, XIII, 1-21).

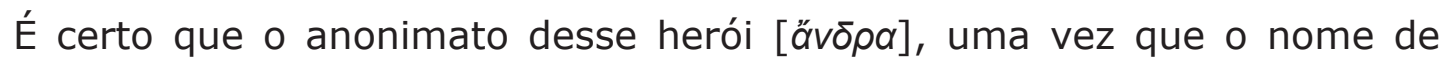
Odisseu [Ulisses] só será mencionado vinte versos após o início do poema, somado à imprecisão da Odisseia em relação à sua primeira caracterização, permitiriam que a passagem pudesse se referir a tantos outros heróis, também sobreviventes de Troia, como Menelau, Agamêmnon e Diomedes. A Odisseia, nesse sentido, é já uma forma distinta de ver o herói. Seu tema é um homem que, embora individualizado em certa medida, pode se confundir com outros dos guerreiros que regressaram de Troia como heróis, ou que, em outras palavras, não precisaram morrer na guerra para serem reconhecidos como heróis. 


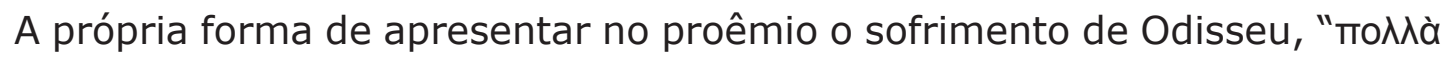

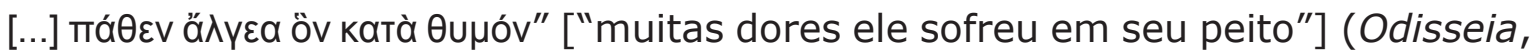
I, 4-5) não é uma forma comum de caracterizar o herói na épica. De fato, na Ilíada, o herói também é apresentado como aquele que sofreu dores em seu coração - das quatro vezes em que a expressão aparece, duas vezes refere-se a Aquiles (Ilíada, IX, 321; XVI, 55). Na Odisseia, essa caracterização ocorre também apenas quatro vezes, com a primeira ocorrência aparecendo logo no início do primeiro canto. Em outras duas vezes, a expressão faz referência a Odisseu, pela voz do narrador (Odisseia, XIII, 90) e pela do próprio Odisseu, que fala sobre si mesmo (Ibidem, XIII, 267); e caracteriza, por fim, Eumeu como aquele "quem muito sofre em seu peito" (Ibidem, XV, 487) (PUCCI 1982).

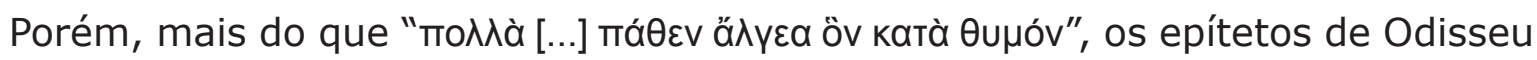

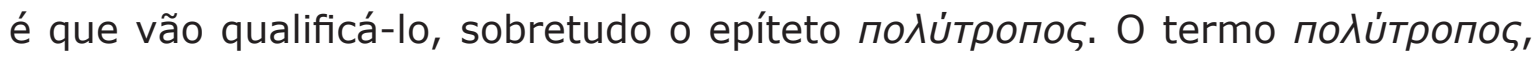
que combina um sentido ativo (significando "com muitas voltas na mente") com um passivo ("que é levado de um lugar a outro"), é usado no proêmio (Ibidem I, 1) e no Canto X (Ibidem 330) para caracterizar Odisseu. Provavelmente, o epíteto é usado de forma intencionalmente ambígua pelo poeta da Odisseia, de modo a confundir um sentido com o outro, pois o termo полúтропо , além de designar por duas vezes Odisseu, aparece no poema somente outras duas vezes, não coincidentemente por certo, designando Hermes. Trata-se, portanto, de uma qualidade divina, embora um único homem seja também seu portador.

Além desse, Odisseu recebe vários poly-epítetos, como noגúaıvos [de

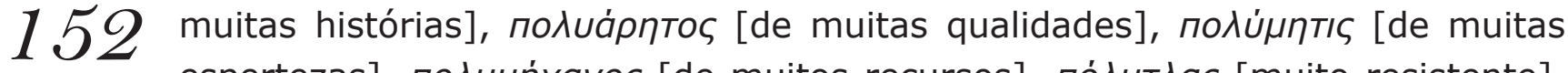

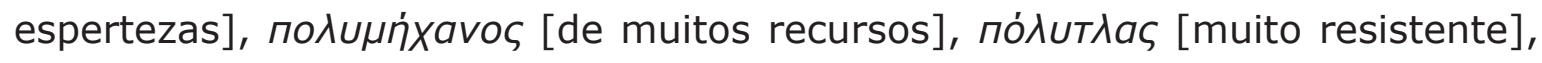
noגú $\varphi \rho \omega v$ [muito inventivo]. Eles são importantes na economia do poema, porque é graças às qualidades a que eles fazem referência que Odisseu pode completar, depois de dez anos, um vóotos [retorno] que parecia interminável. É em função de sua habilidade e de sua astúcia que ele pode sobreviver às aventuras. Seu retorno é, na verdade, um retorno de lugares escondidos - como a ilha de Polifemo, de Calipso, de Circe, do Hades, da Esquéria -, os quais são, de forma figurada, como propõe Pietro Pucci (1982), emblemas de sua morte. É por meio de suas muitas histórias, qualidades, espertezas, invenções, de seus muitos recursos, em suma, que ele poderá concluir seu retorno, driblando a morte no mar. O retorno à Ítaca do herói, aliás, coroa a ideia de que Odisseu, diferentemente de outros heróis especialmente iliádicos, não precisaria morrer para se tornar herói; ele precisaria, isto sim, reconhecer sua condição de mortal. Em outras palavras, Odisseu é o herói que não morre na guerra, mas que, por isso mesmo, precisa reaprender que é um mortal, e a conquista desse aprendizado se dará à medida que ele ouvir e narrar suas histórias (SEGAL 1994). Se a fama dos heróis já mortos é cantada aos vivos, a fama de Odisseu, ao ser cantada na ilha dos feácios, é ouvida por ele mesmo, uma vez que ele, herói diferente dos outros, a tinha conquistado sem ter perecido. Na ilha dos feácios, ouvindo os cantos de Demódoco sobre sua fama e ouvindo a si mesmo, Odisseu reconhece-se mortal (FINKELBERG 1987), percebendo quão inédita é a sua condição. 
Não é mera coincidência, então, que Plutarco, nascido por volta de 40 d.C. na cidade grega de Queroneia, proponha contemplar e permita ao leitor contemplar em suas Vidas o que é belo e grandioso, em clara referência a

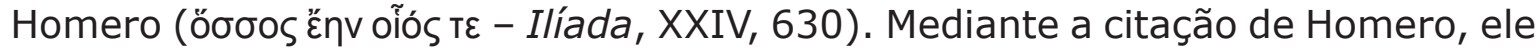
indica, além disso, que Vidas quer desempenhar o papel que teria sido (ou que se imagina que teria sido) aquele da epopeia noutros tempos (HARTOG 1999, p. 21, tradução nossa). ${ }^{1}$ Os limites entre a biografia e a epopeia nesse sentido são claramente reconhecíveis, mas, apesar disso, recolhendo a lembrança de homens grandiosos e belos, tanto um gênero quanto o outro inscrevem-se numa espécie de continuidade dos usos da memória.

Plutarco, que não é o inventor do gênero biográfico, mas talvez o nome mais importante para o seu desenvolvimento na tradição ocidental, convoca e recapitula as ações e as virtudes desses homens eleitos por sua excelência para, com isso, dar vida a um projeto filosófico moralizante. Seu objetivo, em Vidas, é revelar o caráter de seus biografados, para, assim, permitir que cada leitor - e ele mesmo - aperfeiçoe o seu próprio. É o que diz na Vida de Timoleão:

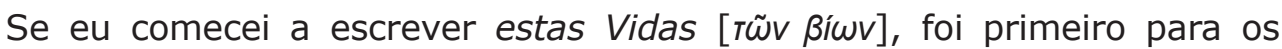
outros, mas é agora para mim mesmo que eu persevero e me alegro nessa empresa. A meus olhos, a história [тп̃ ioropíá é como um espelho com a ajuda do qual eu tento, de certa forma, ajustar minha vida e estar em conformidade com as virtudes [Tờs ápetàs] dos grandes homens. Tenho a

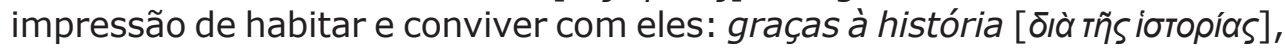
eu ofereço hospitalidade, se assim se pode dizer, a cada um deles, vez a vez, acolhendo-os e guardando-os perto de mim. Eu contemplo como

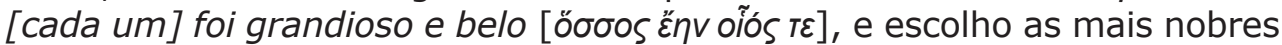
e as mais belas de suas ações a fim de torná-las conhecidas (PLUTARCO Vida de Timoleão, 1, grifo nosso, tradução nossa). ${ }^{2}$

No pensamento grego, de fato, o caráter tem um elemento ético que define o que é certo e o que é errado, o que é virtude e o que é vício, em relação às normas estabelecidas, e o caráter de cada um seria, assim, demonstrado por suas ações. Em termos vocabulares, o mais próximo disso que se tem na língua

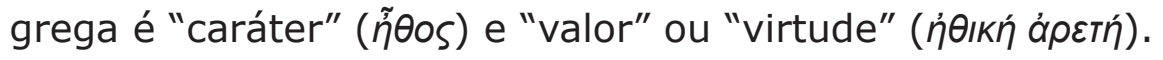

Diodoro (c. 90-30 a. C.), em provável resposta a Políbio (c. 203-120 a. C. ), confirma a função ética da redação das biografias, embora a passagem seja pouco dada à interpretação por ausência de referências precisas a seu contexto, sendo, na verdade, um fragmento transmitido em De virtutibus et vitiis, de Constantino Porphyrogeneta:

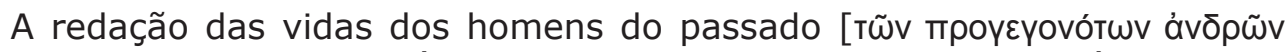
ทे Tũv ßíwv ávaypạń] dá trabalho aos autores, mas ela não é de pouca utilidade para a sociedade; mostrando com franqueza as boas [e as más]

\footnotetext{
${ }_{1}^{1}$ Texto original: Par cette citation d'Homère, il indique, en outre, que les Vies voudraient jouer aujourd'hui le rôle qui avait été (ou qu'on imaginait qu'avait été) celui de l'épopée autrefois.

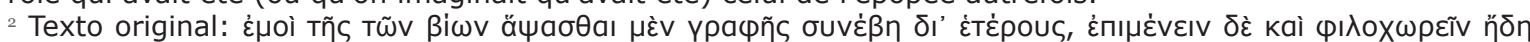

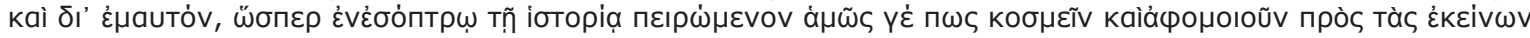

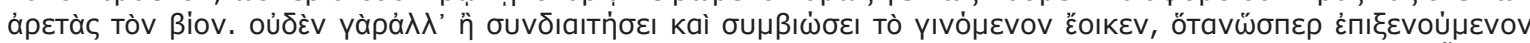

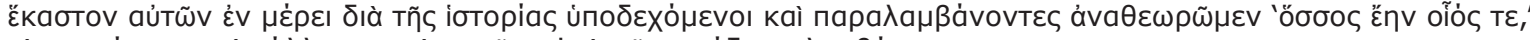

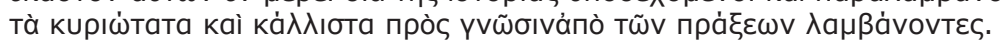


ações, ela exalta os bons e diminui os maus utilizando-se de elogios e

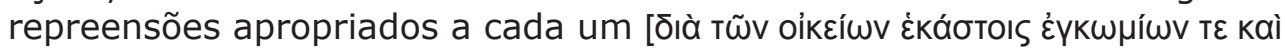
$\psi o ́ \gamma \omega v]$. O elogio, pode-se dizer, é um prêmio gratuito dado pela virtude, enquanto a repreensão é um castigo de baixa qualidade sem violência física, e é belo para as gerações futuras terem como princípio que a lembrança através da qual se julga um homem digno depois de sua morte

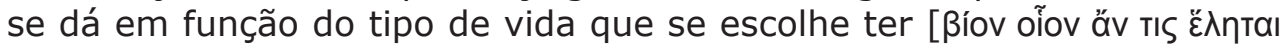

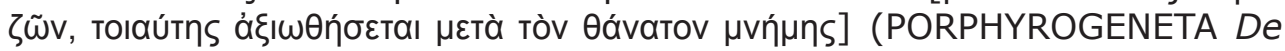
virtutibus et vitiis, $\mathrm{X}, 12,1-2$, tradução nossa).

Outra referência à redação das biografias é Phílon de Alexandria (20 a. C.-50 d. C. ), que analisa o Pentateuco dividindo-o em três partes e dizendo ser a segunda "a redação das biografias boas e más e os castigos e recompensas atribuídos a uns e outros a cada geração" (PHÍLON DE ALEXANDRIA, Praem. 2.1).3

Essa visada moral, contudo, não deve ser entendida necessariamente como um elemento de contraste fundamental em relação à historiografia (FRAZIER 2010), pois não é à toa que François Hartog teria entendido a biografia de Plutarco como uma espécie de "reformulação [ou alternativa] do programa de uma história mestra da vida" (HARTOG 1999, p. 177), em relação ao projeto de Cícero, obviamente. Para respeitar a verdade, como o historiador precisa fazer, Plutarco confronta-se, mesmo que visando pintar seus heróis, com dados que exigem ora elogios, ora repreensões. As fraquezas ou vícios da alma, no entanto, fazem parte da pintura que cria. Nessas pinturas, seus homens, mesmo sendo grandes, têm também imperfeições e falhas, sendo humanos somente por isso.

O primeiro excerto citado de Plutarco, da Vida de Timoleão, torna já evidente, como as funções da epopeia e da biografia de apresentar as grandes ações, o que elas têm de belo e grandioso, se misturam ["Eu contemplo como

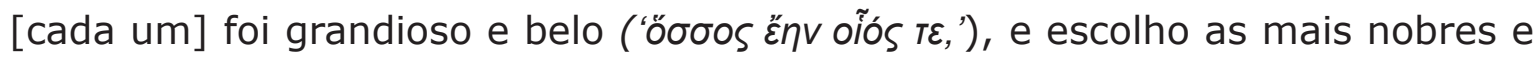
as mais belas de suas ações a fim de torná-las conhecidas" - PLUTARCO Vida de Timoleão, 1], bem como faz por demonstrar que as ideias mesmas de biografia (ßís) e de história (iбторía) se confundem ["Se eu comecei a escrever estas Vidas ( $T \tilde{\omega} v \beta i ́ \omega v)$, foi primeiro para os outros [...]. A meus olhos, a história ( $t \tilde{\eta}$ ioropía) é como um espelho, com a ajuda do qual eu tento, de certa forma, ajustar minha vida e estar em conformidade com as virtudes (Tòs ápetòs) dos grandes homens." - PLUTARCO Vida de Timoleão, 1]. Um segundo trecho das Vidas, que também merece ser citado, confirma a fluidez nos limites entre história e da biografia no vocabulário de Plutarco. Curiosamente, ao passo que nossa primeira citação das Vidas parece aproximar história e biografia, nesta segunda o autor parece se arriscar a diferenciá-los:

Escrevendo neste livro a vida de Alexandre, rei da Macedônia, e de César, que derrotou Pompeu, não se fará outra introdução, em razão do grande número de fatos importantes que concernem ao tema, a não ser este pedido ao leitor: peço aos meus leitores que não cometam a maldade de buscar nestes escritos todos os eventos célebres nem detidamente, posto que abreviamos a maior parte. Por um lado, escrevo não histórias

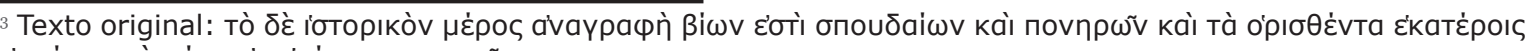

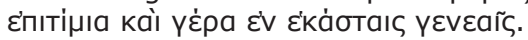




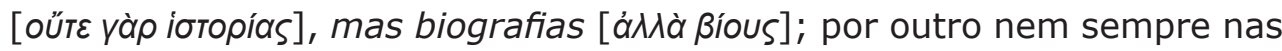
ações mais famosas se demonstra a virtude ou o vício, mas muitas vezes as coisas pequenas, uma palavra, uma brincadeira manifestam mais o caráter de alguém que as batalhas sangrentas, os maiores combates e assaltos (PLUTARCO Vida de Alexandre, 1, grifo nosso, tradução nossa) ${ }^{4}$

Dessa forma, com Plutarco, vemos os limites entre história e biografia serem pensados. Eles não estão definidos, dados, estão sendo de fato pensados. Plutarco, justamente, não demonstra ter medo em dividir com seu leitor o que se poderia chamar de pequenas conclusões (por oposição a conclusões definitivas) acerca do que seria a história e do que seria a biografia. Na Vida de Timoleão, as duas são como um espelho, servem a um mesmo propósito e, assim, confundem-se. Já na Vida de Alexandre, elas são distintas: "escrevo

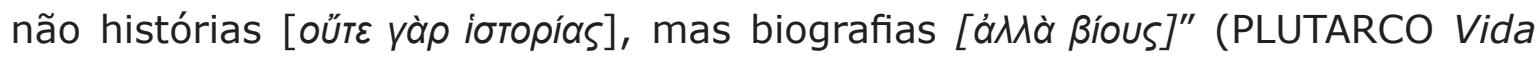
de Alexandre, 1). Ainda na Vida de Alexandre, outra confluência, desta vez entre biografia e epopeia, parece se desfazer. Atento aos detalhes - as coisas pequenas, uma palavra, uma brincadeira - e não apenas às grandes ações - as batalhas sangrentas, os maiores combates e assaltos -, essas sim o interesse da epopeia, nosso autor irá buscar a vida de cada homem. Assim, o que pode em princípio ter parecido apenas uma reformulação da poesia épica vai se mostrar bem diferente, pois "nem sempre nas ações mais famosas se demonstra a virtude ou o vício" (PLUTARCO Vida de Alexandre, 1). Tendo julgado seus grandes homens somente a partir de seus grandes feitos, a poesia de heróis não teria estabelecido sua fama correta.

Na discussão em torno dos gêneros em Plutarco, o termo "biografia" tem sido o ponto da discórdia. Como trabalho literário, a biografia recebe do vocabulário grego exatamente o termo "vida" (ßios). O prólogo às Vidas de Alexandre e César, no qual Plutarco enfatiza sua prioridade em narrar não eventos políticos e militares, mas detalhes importantes, tem sido determinante tanto para diferenciar biografia (Bios) e história (iбторía) no pensamento antigo quanto para aproximá-los. Em geral, para a crítica que argumenta a ausência de fronteiras claras entre um gênero e outro, essas mesmas fronteiras são igualmente pouco definidas em outras formas discursivas como o encômio e a monografia histórica. As diferenças entre essas formas seriam, assim, construções individuais dos próprios autores com vistas a tornar seu trabalho distinguível aos olhos do público em relação ao trabalho de seus rivais. Em conclusão, a distinção usada por Plutarco logo nas primeiras linhas da Vida de Alexandre não poderia ser tomada como distinção universal e, na verdade, não poderia nem mesmo ser aplicada de forma homogênea a todo seu trabalho. Timothy E. Duff (1999) menciona, nesse sentido, outras passagens, em que o autor escolhe "história" (ібторía) para referir-se a qualquer tipo de narrativa,

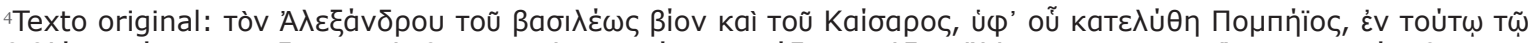

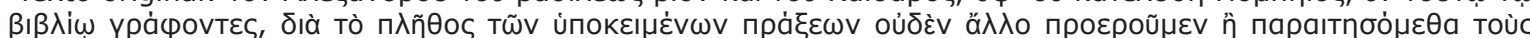

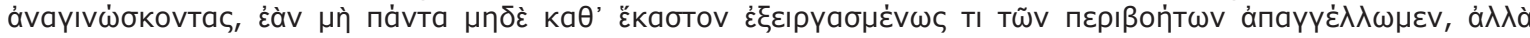

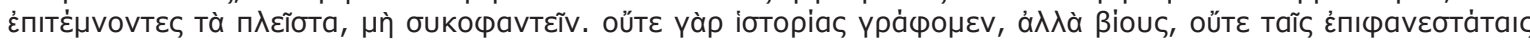

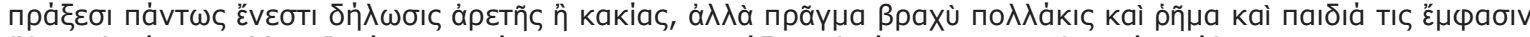

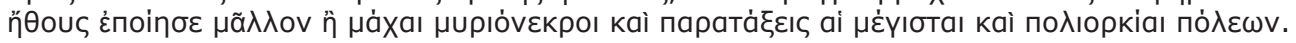


fazendo do termo uma saída generalizante, como, por exemplo, no início do texto das Vidas de Teseu e Rômulo (PLUTARCO Vidas de Teseu e Rômulo, 1). $\mathrm{Na}$ passagem, Plutarco parece referir-se, ao usar o termo "história", tanto à

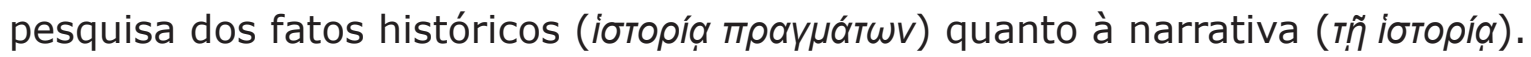

Uma segunda distinção - e, a nosso ver, mais bem delineada do que aquela entre história e biografia - seria a que Plutarco faz entre história e mito, que aparece no prefácio às Vidas de Teseu e Rômulo: "eu espero - diz Plutarco - que o mito ( a ela para tomar a forma da história ( $\lambda \alpha \beta \varepsilon \tilde{I}$ i iotopías ö $\psi$ IV) (PLUTARCO Vida de Teseu, 1). ${ }^{5}$ A passagem em questão evoca, claramente, os trabalhos de Tucídides (2001, I, 1), para quem também importou a grandeza dos feitos a serem narrados, bem como importou buscar a verdade sem ceder ao prazer e aos encantos do mito.

À luz da evidência apresentada até agora, todavia, ninguém erraria se mantivesse o ponto de vista de que os fatos na antigüidade foram muito próximos de como os descrevi, não dando muito crédito, de um lado, às versões que os poetas cantaram, adornando e amplificando os seus temas, e de outro considerando que os logógrafos compuseram as suas obras mais com a intenção de agradar aos ouvidos que de dizer a verdade, uma vez que suas estórias não podem ser verificadas, e eles em sua maioria enveredaram, com o passar do tempo, para a região

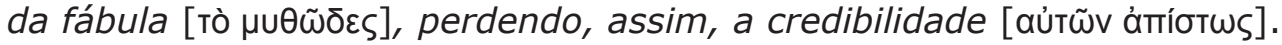
Deve-se olhar os fatos como estabelecidos com precisão suficiente, à base de informações mais nítidas, embora considerando que ocorreram em épocas mais remotas. Assim, apesar de os homens estarem sempre inclinados, enquanto engajados numa determinada guerra, a julgá-la a maior, e depois que ela termina voltarem a admirar mais os acontecimentos anteriores, ficará provado, para quem julga por fatos reais, que a presente guerra terá sido mais importante que qualquer outra ocorrida no passado (TUCÍDIDES, I, 21, grifo nosso).

Duff (1999, p. 18), entretanto, sugere que, tal como a distinção entre biografia e história não poderia ser tomada de forma universalizante para se entender a obra de Plutarco, tampouco essa distinção entre mito e história o poderia.

\section{Estudo de caso: Alexandre e sua admiração por Diógenes}

Tomemos um breve exemplo para testarmos o argumento. No capítulo XIV da Vida de Alexandre, lemos sobre a conhecida passagem em que Diógenes Cínico diz a Alexandre, o Grande, quem, em certa ocasião, havia Ihe perguntado

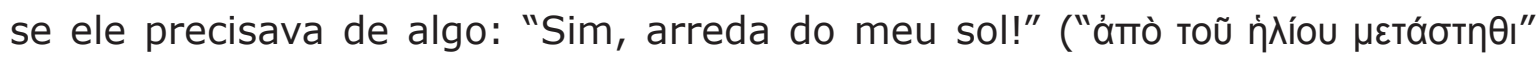
- PLUTARCO Vida de Alexandre, 14). No mesmo trecho, Plutarco insiste na admiração de Alexandre por esse filósofo que viria a ser tão incompreendido por seu tempo e pelas gerações vindouras. O filho de Filipe teria dito, segundo

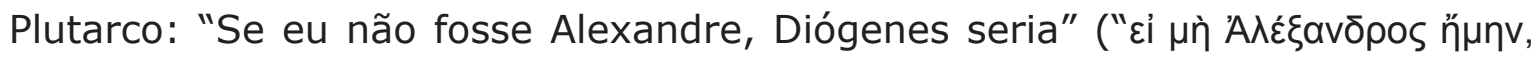

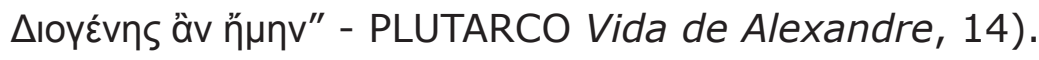

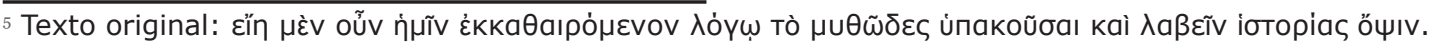


Ora, a fala de Alexandre é citada novamente por Plutarco no texto Sobre a fortuna ou a virtude de Alexandre. Nele, Plutarco conta que Alexandre, o Grande, insistindo em sua admiração por Diógenes Cínico, teria dito que, tal como fizera o filósofo de Sínope, também ele falsificaria a moeda. ${ }^{6}$ Alexandre propunha alterar o caráter da cunhagem nas peças fornecidas pelos povos conquistados, de modo a imprimir sobre elas a marca do Estado grego. Nas palavras de Plutarco, Alexandre alteraria a moeda [vó

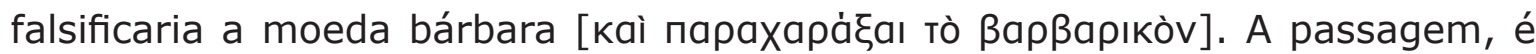
preciso dizer, deve ser entendida como uma espécie de conclusão para a análise que o historiador faz do imperador macedônico. Segundo Plutarco, Alexandre teria misturado aos costumes gregos os costumes de outros povos, civilizando cada país, disseminando a justiça helênica e a paz sobre cada nação, alargando os limites do mundo conhecido. A admiração de Alexandre por Diógenes não revela, assim, nenhuma insatisfação com seu exercício de poder, o que poderia se depreender da afirmação. Apesar de sua fala ("Se eu não fosse Alexandre, Diógenes seria" - PLUTARCO Vida de Alexandre, 14), Alexandre não desejava ser filósofo como Diógenes, mesmo tendo-o em grande estima, por já enxergar em si, enfim, um filósofo em ação, um filósofo em seu propósito maior, qual

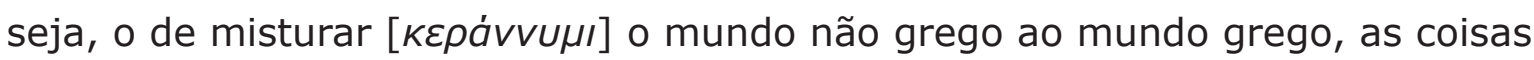
dos bárbaros às coisas gregas. Sem desejar abandonar seu lugar, Alexandre admirava a simplicidade e a autonomia (o bastar-se a si mesmo) de Diógenes, e não hesitava em tomar como lição alguns de seus costumes: "[...] Por minha causa, aqueles [sábios] precisam vir conhecer Diógenes bem como ele precisa conhecê-los. E eu também, como Diógenes, devo alterar as moedas e falsificar as bárbaras com a efígie grega" (PLUTARCO Sobre a fortuna ou a virtude de Alexandre, 332, tradução nossa). ${ }^{7}$

Alexandre julgava-se, assim, um filósofo em ação por enxergar em sua conquista do mundo conhecido a atitude filosófica de civilizar cada região atravessada, estimulando a troca de costumes numa espécie de promoção do cosmopolitismo. É, então, para arrematar a explicação que Plutarco faz seu Alexandre dizer sobre a fabricação de uma moeda nova, usando o verbo парако́пт $\omega$, que indicaria a falsificação num sentido mais técnico. Ele também utiliza o ambíguo парахара́тாєıv, provavelmente, o verbo sempre utilizado nas alusões à história da falsificação da moeda por Diógenes: "eu também,

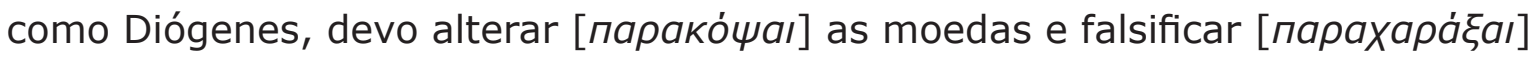

\footnotetext{
${ }^{6}$ Logo na abertura do livro consagrado a Diógenes Cínico, D. Laércio narra a história em que a falsificação da moeda aparece como a causa do exílio de Diógenes e a oportunidade para sua iniciação filosófica (DIÓGENES LAÉRCIO 1966, VI, 20-21). O tema da falsificação da moeda é, na verdade, um tema que aparece em D. Laércio não apenas nessa passagem, mas que está no centro de uma tradição que fez desse episódio da vida de Diógenes Cínico um exemplo privilegiado da doutrina cínica. É que a plasticidade das possibilidades interpretativas da passagem soma-se à conservação da anedota pela tradição de modo a confirmar um dos traços fundamentais do corpus cínico: a recusa do uso da moeda corrente, entendida como uma escolha que não exatamente refuta a moeda corrente, mas refuta seu uso corrente e que inverte esse uso para deixar mais evidente sua crítica a ele (FLORES-JÚNIOR 2000). Em outras palavras, Diógenes Cínico, tendo ou não falsificado a moeda, ter-se-ia aproveitado da história, tal como a tradição cínica o faria. O episódio narrado por D. Laércio sobre Diógenes Cínico é aludido por outras fontes, dentre elas Plutarco, que, de forma rápida, mas não ingênua, explora, senão a polifonia, ao menos a ambiguidade do evento.

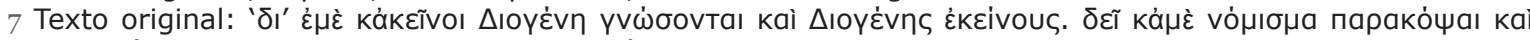

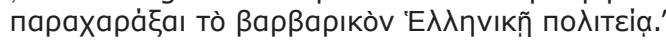


as bárbaras com a efígie grega" (PLUTARCO Sobre a fortuna ou a virtude de Alexandre, 332). ${ }^{8}$

Nesse sentido, a expressão, referida a Diógenes, parece tirar proveito, no relato de Plutarco, de seu valor histórico, isto é, de sua permanência na tradição (independentemente de sua veracidade), para enriquecer seu valor metafórico. Se usada no sentido denotativo, ela explicitaria, na prática, a solução que Alexandre tinha em mente para criar sua nova moeda: alterar a moeda dos bárbaros. No sentido figurado, a expressão apenas coroaria, metaforicamente, o projeto de Alexandre de helenização do mundo, projeto no qual tanto o conquistador quanto o conquistado contribuiriam para a formação do império, agremiando-se num mesmo espaço: um daria a moeda e o outro imprimiria sobre ela um novo caráter.

Em geral, as alexandras eram moedas de prata e de ouro que seguiam o valor ponderal do modelo ático do quinto século a. C. e nas quais se via como legenda o nome de Alexandre no genitivo, indicando a posse "de Alexandre"

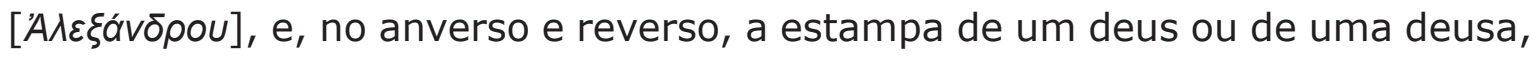
conforme seu metal. Sabe-se que, no caso de moedas a serem forjadas iguais num grande número de cidades (o que acontecia com as moedas emitidas para servirem à extensão de um reino ou um império como o de Alexandre), gravavase sobre elas uma marca para indicar o lugar da fundição das séries. Mas, à parte esses sinais que diferenciavam cada série, as moedas fabricadas nas diferentes regiões submetidas a um único poder tinham uniformemente os mesmos tipos e as mesmas legendas. Sabe-se ainda que a emissão de moedas com o nome de Alexandre, sobretudo, nos últimos anos de seu reinado, representa um fenômeno maior na história das moedas. E tal observação, a de que a emissão de alexandras representaria um fenônomeno maior na história das moedas, funda-se na ideia implícita de uma massa metálica essencialmente estável, que teve significativo aumento com os butins de guerra orientais capturados pelo filho de Filipe (BABELON 1979; CALLATAŸ; DEPEYROT; VILLARONGA 1993). Tendo em vista a amplitude da fabricação das moedas durante o reinado de Alexandre, é de se desconfiar, portanto, que o rei tenha requerido o essencial da massa metálica disponível (LE RIDER 2003), parecendo natural ao julgamento de Plutarco, se o sentido da expressão for literal, que a nova moeda, a moeda imperial, estaria destinada a suplantar toda a variedade, fazendo desaparecer as anteriores. ${ }^{9}$

A possibilidade de que uma confirmação histórica mínima se some ao

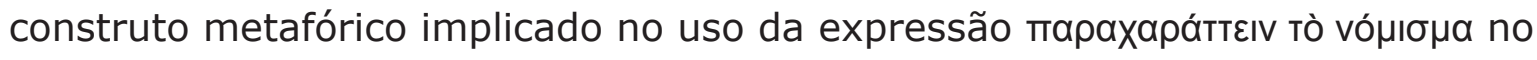
episódio de Alexandre mostra-se, contudo, tão possível quanto incerta. Essa fragilidade da fronteira entre o histórico e o metafórico, que, em definitivo, enriquece a expressão pode ser entendida à luz da disposição que o vocabulário

\footnotetext{
${ }^{8}$ A explicação não reproduz aquilo que Alexandre teria dito, tal como "se eu não fosse Alexandre, Diógenes seria" (o que já é um registro de Plutarco e, apenas indiretamente, de Alexandre), mas aquilo que Plutarco teria imaginado como possível explicação de Alexandre para tal afirmação.

9 Segundo Babelon (1979), nem sempre, nas áreas conquistadas, a moeda de Alexandre substituiu por completo a local.
} 
grego desenvolveu para certa solidariedade entre verdadeiro e falso e que permeia tanto a oposição quanto a aproximação entre história e biografia e biografia e mito, tornando frágeis também aí as fronteiras.

\section{Breves considerações finais}

Se não são poucas as discussões a respeito das Vidas de Plutarco em relação aos gêneros história e biografia, é possível observar que, em geral, a fortuna crítica reivindica para a obra e seu autor o pertencimento a um ou outro. O presente texto busca, então, contribuir com a tradicional discussão, apresentando ao confronto dos gêneros uma possibilidade ligeiramente distinta de leitura, qual seja a de que Plutarco está, à medida que escreve suas Vidas, construindo e reconstruindo sua concepção sobre o que seria história e o que seria biografia, refletindo, de fato, sobre como elas se confundiriam, quais seriam suas interseções, mas, sobretudo, a que serviriam.

Nesse sentido, para arriscarmos uma conclusão, tendo em vista, em primeiro lugar, esse episódio da fala de Alexandre sobre sua relação com Diógenes ["Se eu não fosse Alexandre, Diógenes seria" - PLUTARCO Vida de Alexandre, 14]; em segundo, o pedido que faz a seu leitor logo na abertura do texto ["peço aos meus leitores que não cometam a maldade de buscar nestes escritos todos os eventos célebres nem detidamente, posto que abreviamos a maior parte" - PLUTARCO Vida de Alexandre, 1]; em terceiro, seu método, o de buscar também nas passagens menores da existência do biografado fórmulas para se demonstrar sua virtude ou seu vício, seria possível reivindicar a diferença da biografia em relação à história, conforme os elementos que usa para distinguilas. Mas, igualmente, se considerarmos o que o autor diz na Vida de Timoleão, a dúvida com respeito aos gêneros retorna, pois, afinal, parece certamente haver ali um propósito de orientação de caráter, cujo pressuposto seria: "a história

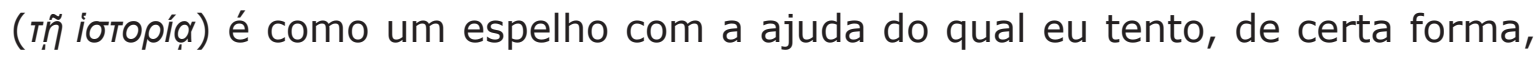
ajustar minha vida e estar em conformidade com as virtudes (тàs ápeTàs) dos grandes homens" (PLUTARCO Vida de Timoleão, 1).

Uma interpretação possível, que não delimita os gêneros ou os dissolve completamente em um só, seria pensar que Plutarco, embora dê continuidade à tradição à que pertence, escolhendo grandes homens e narrando seus grandes feitos, não o faz só dessa forma, já que, no caso aqui apresentado, ele se interroga sobre as virtudes e os vícios de seu biografado tanto atentando para seus detalhes, quanto para as grandes façanhas do biografado, e, nesse ponto, inova e se desvencilha da mesma tradição que, em parte, segue. Se, para falar de Alexandre, Plutarco conta feitos grandiosos e belos à maneira da poesia épica

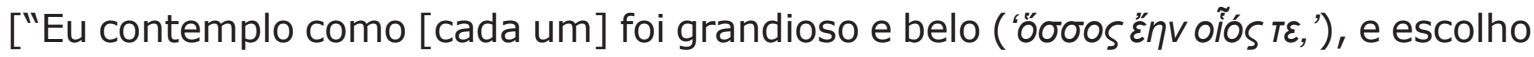
as mais nobres e as mais belas de suas ações a fim de torná-las conhecidas" PLUTARCO Vida de Timoleão, 1], ele não dispensa, por outro lado, falar de seus feitos menores ["pois nem sempre nas ações mais famosas se demonstra a virtude ou o vício, mas muitas vezes as coisas pequenas, uma palavra, uma brincadeira manifestam mais o caráter de alguém que as batalhas sangrentas, os maiores combates e assaltos" - PLUTARCO Vida de Alexandre, 1]. 
Parece haver, assim, com a tentativa de Plutarco de humanizar os grandes homens que escolhe para biografar, uma consequente reflexão epistemológica sobre a história e a biografia que, no entanto, mesmo dando mostras da busca do estabelecimento de limites, importa-se mais com o objetivo proposto, o de tornar o biografado um espelho para o leitor, do que propriamente com esse estabelecimento de limites. Em suas Vidas, fazendo biografias, ele mostra que a história é composta de feitos maiores e também menores, assumindo que seus homens têm vícios e virtudes. Com isso, Alexandre, Timoleão e os outros, ao terem suas Vidas contadas dessa forma por Plutarco, ficam perto de si e perto de nós: "tenho a impressão de habitar e conviver com eles: graças à história

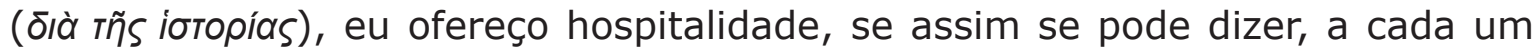
deles, vez a vez, acolhendo-os e guardando-os perto de mim" (PLUTARCO Vida de Timoleão, 1). A biografia e a história, a biografia ou a história, a biografia graças à história em Plutarco, enfim, aproximam o biografado de si e de nós porque o humanizam, enxergando nele vícios e virtudes, grandes feitos e outros nem tão grandes assim, e isso é o que parece mais ter importado ao autor.

\section{Referências bibliográficas}

BABELON, Ernest. Introduction générale à l'étude des monnaies de I'antiquité. New York: Arno Press, 1979.

CALLATAŸ, François; DEPEYROT, Georges; VILLARONGA; Leandre. L'argent 160 monnayé d'Alexandre le Grand à Auguste. Bruxelles: Cercle d'Études Numismatiques, 1993.

DE JONG, I. F. A narratological commentary on the Odyssey. Cambridge: Cambridge University Press, 2002.

DIÓGENES LAÉRCIO. Diogenis Laertii vitae philosophorum. Oxford: Ed. Long, H.S.; Clarendon Press, 1966. 2 v.

DUFF, T. E. Plutarch's lives. Exploring virtue and vice. Oxford: Oxford University Press, 1999.

FINKELBERG, M. The First Song of Demodocus. Mnemosyne, v. 40, s. 1, p. 128 $-132,1987$.

FLORES-JÚNIOR, Olimar. Canes sine coda: filósofos e falsários: uma leitura do cinismo antigo a partir da literatura relativa a Diógenes de Sínope. Dissertação (Mestrado em Filosofia) - Programa de Pós-Graduação em Filosofia, Universidade Federal de Minas Gerais, Belo Horizonte, 1999.

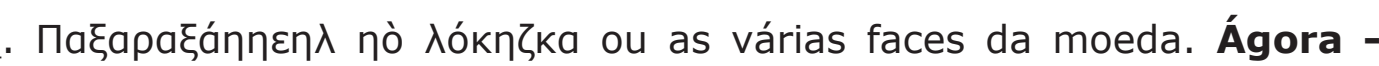
Estudos Clássicos em Debate, n. 2, p. 21-32, 2000.

FRAZIER, Françoise. Bios et Historia. À propos de l'écriture biographique dans les Vies Parallèles de Plutarque. Dialogues d'histoire ancienne, sup. 4.1, p. 155-172, 2010. 
HARTOG, François. L'histoire: d'Homère à Augustin. Préfaces des historiens et textes sur l'histoire réunis et commentés par François Hartog, traduits par Michel Casevitz. Paris: Éditions du Seuil, 1999.

HOMERI. Homeri Ilias. Ed. Allen, T.W. Oxford: Clarendon Press, 1931.

. Homeri Odyssea. Ed. Peter von der Mühll, P. Basel: Helbing \& Lichtenhahn, 1962.

HOMERO. Ilíada. Tradução de Frederico Lourenço.São Paulo: Penguin Classics; Companhia das Letras, 2013.

Odisseia. Traduzido por Frederico Lourenço. São Paulo: Penguin Classics; Companhia das Letras, 2011.

LE RIDER, Georges. Alexandre Le Grand: Monnaie, finances et politique. Paris: Presses Universitaires de Frances, 2003.

PHILON D'ALEXANDRIE. De praemiis et poenis, de exsecrationibus. Introduction, traduction et notes. Paris: Éditions du Cerf, 1961. Tome 27.

Philonis Alexandrini opera quae supersunt. Berlin: Ed. Cohn, L.; Reimer, 1962. v. 5.

PLUTARCH. On the fortune of Alexander. In: PLUTARCH. Plutarch's Moralia. Transl. Frank Cole Babbit. W. Heinemann: Harvard University Press, 1961. 15 vol.

Plutarch's Lives. English Translation by Bernadotte Perrin. Cambridge, MA: Harvard University Press. London: William Heinemann Ltd., 1918.

Plutarchi moralia, vol. 2.2. Ed. Nachstädt, W. Leipzig: Teubner 1971 [1935].

. La fortune ou la vertu d'Alexandre. In: PLUTARQUE. Oeuvres morales. [Traités 20-22], La fortune des Romains, La fortune ou la vertu d'Alexandre, La gloire des Athéniens. Traduction: Françoise Frazier. Paris: Les Belles Lettres, 1990. Tome V. 1ère partie.

PUCCI, Pietro. The Proem of the Odyssey. Arethusa, v. 15, p. 39-62, 1982.

SEGAL, Charles. The Phaeacians and Odysseus' Return. In: SEGAL, Charles. Singers, Heroes, and Gods in the Odyssey. Ithaca; London: Cornell University Press, 1994.

THUCYDIDIS. Thucydidis historiae. Ed. H. S. Jones, J. E. Powell. Oxford: Clarendon Press, 1967. 2 v.

TUCÍDIDES. História da Guerra do Peloponeso. 4. ed. Prefácio de Helio Jaguaribe; traduzido do grego por Mário da Gama Kury. Brasília; São Paulo: Ed. Universidade de Brasília, Instituto de Pesquisa de Relações Internacionais; Imprensa Oficial do Estado de São Paulo, 2001. 